\title{
Health Communication in Media: An Analytical Study of Coverage of World Blood Donor Day in Leading National Dailies from Jaipur Hemant Kumar Pandey ${ }^{1}$, Subhash Kumar ${ }^{2}$, Prabhat Dixit ${ }^{3}$
}

${ }^{1}$ Research Scholar, Department of Journalism and Mass Communication, Manipal University Jaipur, India; ${ }^{2}$ Associate Professor and Head, Department of Journalism and Mass Communication, Manipal University Jaipur, India; ${ }^{3}$ Assistant Professor, Department of Journalism and Mass Communication, Manipal University Jaipur, India.

\begin{tabular}{|c|c|c|c|c|c|c|c|c|}
\hline Abstract & Introduction & Methodology & Results & Conclusion & References & Citation & \multicolumn{2}{|c|}{ Tables / Figures } \\
\hline \multicolumn{9}{|c|}{ Corresponding Author } \\
\hline \multicolumn{8}{|c|}{$\begin{array}{l}\text { Hemant Kumar Pandey, Research Scholar, Department of Journalism and Mass Communication, Manipal } \\
\text { University Jaipur, India. } \\
\text { E Mail ID: pandeyhemant82@gmail.com }\end{array}$} & 口iris \\
\hline
\end{tabular}

\section{Citation}

Pandey HK, Kumar S, Dixit P. Health Communication in Media: An Analytical Study of Coverage of World Blood Donor Day in Leading National Dailies from Jaipur. Indian J Comm Health. 2021;33(4):671-675. https://doi.org/10.47203/IJCH.2021.v33i04.023

Source of Funding: Nil Conflict of Interest: None declared

\section{Article Cycle}

Received: 16/09/2021; Revision: 13/11/2021; Accepted:05/12/2021; Published:31/12/2021

This work is licensed under a Creative Commons Attribution 4.0 International License.

\section{Abstract}

Print media is the oldest media for news and information. It includes newspapers, magazines, journals and other printed material etc. The print media is responsible for reporting the latest and accurate news and information. The common people find the plethora of thoughts from the newspapers so that they can formulate their own opinions, ideas and judgment about the issues. Health related stories are an important part of the information published in the newspapers. In this research paper the researcher has undertaken content analysis of four national dailies published from Jaipur city over a period of three years (2019, 2020 \& 2021) on their coverage of 'World Blood Donor Day'.

\section{Keywords}

Health Communication, World Blood Donor Day, Medical Reporting

\section{Introduction}

As we know Print media is known for its credibility. It is believed that whatever is published in newspapers is true and authentic. Newspapers have a wide reach and huge readership and it can be said that campaigning with mass media like newspapers are associated with many benefits. Firstly it can reach a large number of people. Secondly, it is considered to be a credible source of information. Thirdly through the newspapers the readers can be reminded about the issues at hand their beliefs reinforced on regular basis. Newspapers have a large readership throughout the world. They can contribute maximally to health education awareness of people by publishing articles on health related issues. Global daily circulation of newspaper was 5.19 million having a readership of 2.3 billion in 2010 . This was $20 \%$ more than the internet users worldwide. In the age of internet still newspapers are relevant and represent $8 \%$ of total media consumption time (https://www.journalism.org/factsheet/newspapers/). In India Registered newspapers are
82,237 and Hindi language newspapers are leading the race followed by English and other regional languages. Thus, we can say that Newspapers are very important tool to disseminate health education among people and it can bring change in society. (http://rni.nic.in/)

Blood Donation: Gift of life: 'Safe blood saves lives and improves health'. Blood transfusion is needed for women with complications of pregnancy, such as ectopic pregnancies and haemorrhage before, during or after childbirth, children with severe anaemia often resulting from malaria or malnutrition, people with severe trauma following man-made and natural disasters and many complex medical and surgical procedures and cancer patients. It is also needed for regular transfusions for people with conditions such as Thalassemia and sickle cell disease and is used to make products such as clotting factors for people with Haemophilia. There is a constant need for regular blood supply because blood can be stored for only a limited time before use. Regular blood donations by a sufficient number of healthy people are 
needed to ensure that safe blood will be available whenever and wherever it is needed.

According to the World Health Organization (WHO), India suffers from an annual deficit of two million blood units, as only $1 \%$ of Indian population donates blood each year. Every year India requires about five Crore units of blood, out of which only a meagre 2.5 Crore units of blood are available. More than 38,000 blood donations are needed every day. A total of 30 million blood components are transfused each year. (https://www.oneindia.com/india/world-blood-donorday-2017-every-year-india-requires-5-crore-units-ofblood-2464097.html)

Blood is the most precious gift that anyone can give to another person- the gift of life. A decision to donate your blood can save a life or even several if your blood is separated into its components -red cells, platelets and plasma- which can be used individually for patients with specific conditions.

Majorly areas of Health Communication are- Hygiene, immunization, sanitation, population control, environmental pollution control, communicable disease control, deficiency control disease, accident control, reproductive health, maternal health, child health, adolescent health, geriatric health, industrial health, Mental health and Healthy life style.

\section{Aims \& Objectives}

- To analyse the coverage of world blood donor day in four Jaipur based dailies.

- To ascertain the views of the doctors on the coverage.

- To ascertain the views of the journalists on the coverage

\section{Material \& Methods}

The study is based on primary and secondary sources. Besides the review of existing literature, survey and interviews were also conducted. This study was conducted among the National Daily Newspapers (Two English and Two Hindi) of Jaipur from 13 June to 15 June 2019, 2020 and 2021 on World Blood Donor Day. A total 33 people were interviewed; including 17 doctors and 16 Journalists, through questionnaires. Content analysis of four Newspapers was done on following variables, Number of published articles which were related to Blood Donor Day, Types of Articles, News items, Letters to Editor, Editorials, Page of publication, Advertisements, News with Photograph. Newspapers were selected on the basis of their circulation.

\section{Results}

The Table below shows the number of stories published on the World Blood Donor Day in the four newspapers from Jaipur.

The table shows the coverage of the World Blood Donor Day in these four Jaipur based newspapers in 2019, 2020 and 2021.
(Table 1) Dainik Bhaskar published five stories on the World Blood Donor Day in 2019 and allotted space of nine columns. In the year 2020, Dainik Bhaskar published three stories on the Day and allotted seven columns. In 2021, the same newspaper published only two stories and allotted five columns of space. It not only published few stories on the front page but they also published very meaningful, an appealing story with headline 'Jodiye khoon ka Rishta'. Rajasthan Patrika published two stories on the Day in the year 2019 and allotted seven columns. In 2020 the same newspaper published three stories on the occasion and allotted six columns. In 2021 it published four stories on the Day and allotted nine columns of space. Hindustan Times did not publish any story on the World Blood Donor Day in the year 2019. In 2021 it published only one story and allotted four columns of space. In 2021 it did not publish any story on the Day. The Times of India published one story in 2019 on the subject and allotted four columns of space. In 2020, Newspaper published one story and allotted three columns of space and in 2021 it published one story and allotted four columns for it.

(Table 2) It is quite clear that the Hindi newspapers published more stories on the World Blood Donor Day in comparison to the English dailies.

(Table 3) Furthermore among the Hindi dailies Dainik Bhaskar published ten stories in all on the Day in three years while Rajasthan Patrika published nine stories in the same period.

(Table 4) Among the two English dailies The Times of India published three stories on the Day in comparison to Hindustan Time's one story on the same.

\section{Questions for Doctors:}

Ques1- Do you read health related stories in the newspapers?

In the above given (Figure 1), to a question on do you read health related article in the newspaper among the doctors, about 60 per cent respondents favored on the other hand that 40 per cent respondents disagreed on reading health related news in the newspaper.

Ques2- Did you read the stories on the World Blood Donor Day in newspapers?

In the (Figure 2), about health-related article on a particular day (World Blood Donor Day) among doctors, a majority of 69 per cent respondents are preferred to read stories on World Blood Donor Day in the newspaper whereas 31 percent respondents are not interested in reading stories in the newspaper on that particular day.

Ques-3-Were you satisfied with the coverage?

To a question on about the coverage of Health issues in the newspaper among the doctors, in (Figure3) only 25 percent respondents are satisfied with the coverage of health issues in the newspaper, a majority of 60 percent respondents were not satisfied with the coverage of health issues in newspaper, nearly 11 percent doctors responded that the coverage was satisfactory to some extent and 4 percent respondents are satisfactory to a 
large extent with the coverage of health issues in newspaper.

\section{Questions for Media Professionals (Print Journalist)}

Ques1-Does your newspaper publish reports on health issues regularly?

Among the journalist to a question on newspaper published news on health issues regularly the above (Figure4), shows that 50 percent respondents agreed that their newspaper published health related issues Always, about 32per cent respondents exhibits that their newspapers published health related issues Sometimes, around 15 percent respondents shows that their newspaper published health related issues Rarely and only 2 percent respondents are neutral on newspaper published health related issues regularly.

Ques2-Was your newspaper's coverage of World Blood Donor Day adequate?

In the above (Figure 5), its reveals that about 47 percent respondents are favoured on newspaper's coverage was adequate on health issues on World Blood Donor Day while 28 percent respondents are not satisfied with the coverage of health issues on World Blood Donor Day. While nearly 19 percent respondents are agreed to some extent and around 6 percent respondents are agreed to a large extent with the coverage of health issues on World Blood Donor Day in the newspaper

\section{Discussion}

The survey among the doctors revealed that they were not satisfied with the coverage of the World Donor Day in the newspapers. It also showed that the majority of the doctors read health stories. The survey conducted among the media professionals revealed that a large number of them were satisfied with the coverage and they also said that their newspapers published sufficient number of stories on health issues.

\section{Conclusion}

The research showed that Hindi newspapers were ahead of the English ones in publication of health stories. English dailies were found wanting on this count. Newspapers are major sources of factual information and analysis. There is a room for improvement for newspapers of both the languages regarding number of health stories published. The finding could be useful for the press person as well as health experts and Doctors to consider newspaper as medium is promoting and maintaining health status. Another very important fact that if doctors, hospital administration and media houses connect together and share information accordingly with each other then scenario will improve on health issues.

\section{Recommendation}

Through this study it can be put into perspective that newspapers should publish more stories on health issues.
In English newspapers the numbers of health stories are not very satisfactory, which should be increased. Besides the overall coverage of health stories in newspapers should also be substantially increased so that the masses could be benefitted and health awareness can be improved.

\section{Limitation of the study}

Study was based on Jaipur city only and the newspapers were also selected from Jaipur City.

\section{Relevance of the study}

Newspapers are important to spread awareness for any social cause. Through this study researchers tried to find out the coverage of content related blood donor day in newspapers.

\section{Authors Contribution}

All authors contributed equally.

\section{Acknowledgement}

The authors would like to thank all the authors of those books, articles, and journals that were used in preparing this research paper.

\section{References}

1. Rogers, E. M. (2010). Diffusion of innovations. Simon and Schuster.

2. Mefalopulos, P. (2008). Development communication sourcebook: Broadening the boundaries of communication. World Bank Publications.

3. Genevey, R., Pachauri, R. K., \& Tubiana, L. (2013). Reducing inequalities: a sustainable development challenge. The Energy and Resources Institute (TERI).

4. Minakshi, P. C., \& Kumar, R. (2020). Mental Health Problems in Wake of Disaster: A Gendered Perspective. Rupkatha Journal on Interdisciplinary Studies in Humanities, 12(1), 112.

5. Singh, M. K., \& Kumar, S. Health Communication in Digital Era: A Study of Sub-Urban City of Jaipur. Int J Cur Res Rev| 2020;12(20):75.

6. Schiavo, R. Health communication: From theory to practice. John Wiley \& Sons.2013;217

7. Pandey HK, Kumar S. Role of print media in spreading awareness on Coronavirus Disease (COVID-19). Journal of Xi'an University of Architecture \& Technology, 2019;52035212.

8. Dornan C, Hébert PC. The reporting of theoretical health risks by the media: Canadian newspaper reporting of potential blood transmission of... BMC Public Health. 2004;4(1).

9. IFRA, W. (2013). World Association of Newspapers and News Publishers.

10. Commers, M. J., Visser, G., \& De Leeuw, E. Representations of preconditions for and determinants of health in the Dutch press. Health Promotion International, 2000;15(4), 321-332. 


\section{Tables}

TABLE 1 (STORIES PUBLISHED IN DAINIK BHASKAR)

\begin{tabular}{|l|l|l|l|}
\hline Name of Newspaper & Year & Number of stories & \multicolumn{2}{l|}{ Total space } \\
\hline Dainik Bhaskar & 2019 & 5 & 9 Columns \\
\hline Dainik Bhaskar & 2020 & 3 & 7 Columns \\
\hline Dainik Bhaskar & 2021 & 2 & 5 Columns \\
\hline Total & & $\mathbf{1 0}$ & $\mathbf{2 1}$ Columns \\
\hline
\end{tabular}

TABLE 2 (STORIES PUBLISHED IN RAJASTHAN PATRIKA)

\begin{tabular}{|l|l|l|l|}
\hline Name of Newspaper & Year & Number of stories & \multicolumn{2}{l|}{ Total space } \\
\hline Rajasthan Patrika & 2019 & 2 & 7 Columns \\
\hline Rajasthan Patrika & 2020 & 3 & 6 Columns \\
\hline Rajasthan Patrika & 2021 & 4 & 9 Columns \\
\hline Total & & $\mathbf{9}$ & $\mathbf{2 2}$ Columns \\
\hline
\end{tabular}

\section{TABLE 3 (STORIES PUBLISHED IN TIMES OF INDIA)}

\begin{tabular}{|l|l|l|l|}
\hline Name of Newspaper & Year & Number of stories & \multicolumn{2}{|c|}{ Total space } \\
\hline Times of India & 2019 & 1 & Columns \\
\hline Times of India & 2020 & 1 & 3 Columns \\
\hline Times of India & 2021 & 1 & 4 Columns \\
\hline Total & & $\mathbf{3}$ & $\mathbf{1 1}$ Columns \\
\hline
\end{tabular}

TABLE 4 (STORIES PUBLISHED IN HINDUSTAN TIMES)

\begin{tabular}{|l|l|l|l|}
\hline Name of Newspaper & Year & Number of stories & \multicolumn{1}{l|}{ Total space } \\
\hline Hindustan Times & 2019 & 0 & 0 Column \\
\hline Hindustan Times & 2020 & 1 & 4 Columns \\
\hline Hindustan Times & 2021 & 0 & 0 Column \\
\hline Total & & $\mathbf{1}$ & $\mathbf{4}$ Columns \\
\hline
\end{tabular}

\section{Figures}

FIGURE 1 DO YOU READ HEALTH RELATED STORIES IN THE NEWSPAPERS?

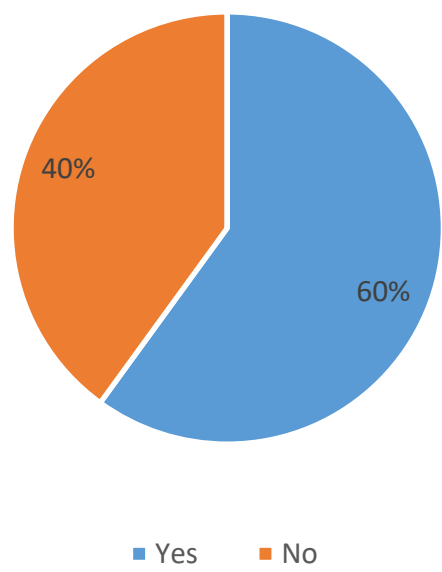

FIGURE 2 DID YOU READ THE STORIES ON THE WORLD BLOOD DONOR DAY IN NEWSPAPERS?

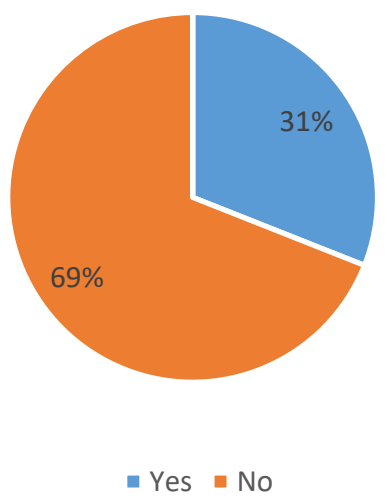


FIGURE 3 - WERE YOU SATISFIED WITH THE COVERAGE?

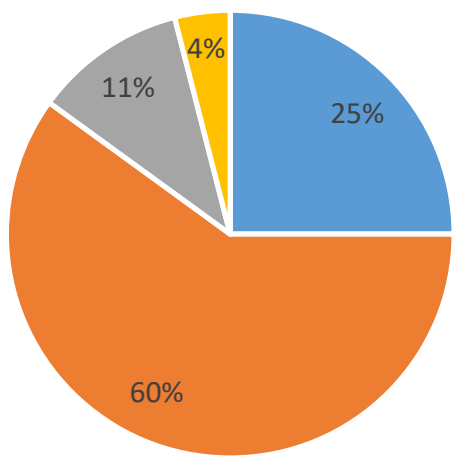

- Yes $\quad$ No $\quad$ To some extent $\quad$ To large extent

FIGURE 4- DOES YOUR NEWSPAPER PUBLISH REPORTS ON HEALTH ISSUES REGULARLY?

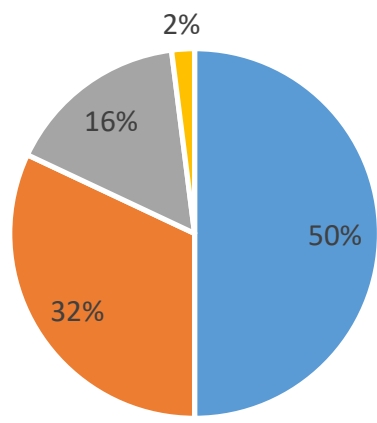

- Always - Sometimes $\|$ Rarely - con't say
FIGURE 5- WAS YOUR NEWSPAPER'S COVERAGE OF WORLD BLOOD DONOR DAY ADEQUATE?

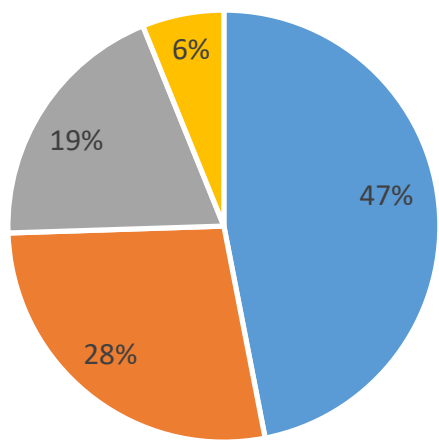

- Yes $\quad$ No $\quad$ To some extent $\quad$ To large extent 